\title{
Risk of endometrial polyps in women with endometriosis: a meta-analysis
}

\author{
Qiao-Mei Zheng ${ }^{1 \dagger}$, Hong-luan Mao ${ }^{1 \dagger}$, Yan-Jing Zhao ${ }^{2}$, Jing Zhao ${ }^{1}$, Xuan Wei ${ }^{1}$ and Pei-Shu Liu*
}

\begin{abstract}
Background: Endometrial polyps (EP) and endometriosis are both estrogen-dependent overgrowths of the endometrium. Several studies have shown a higher frequency of EP in endometriosis patients when compared with women without endometriosis. Therefore, we performed a meta-analysis to investigate the risk of EP in women with endometriosis.

Methods: This meta-analysis searched for articles published between 1964 and 2014 in PubMed, Embase, and Cochrane Library, as well as in Chinese databases, including CNKI, VIP and Wanfang, regarding the association between endometriosis and EP. Nine cohort studies and one case-control study including 2896 women were included in this meta-analysis. The EP risk was evaluated using relative risk (RR) with a $95 \%$ confidence interval (CI). Heterogeneity, small study effect and publication bias were assessed using Higgins $\mathbf{l}^{2}$, sensitivity analysis and funnel plots, respectively.

Results: The risk of EP increased in women with endometriosis compared with those without endometriosis (the pooled RR, 2.81; $95 \% \mathrm{Cl}$, 2.48-3.18). No significant heterogeneity, small study effect or publication bias was found. The risk of EP slightly increased in women with endometriosis at stages 2-4 compared with those at stage 1 (Pooled effect size: stage 2 versus stage 1, RR, 1.22, $95 \% \mathrm{Cl}, 1.04-1.42$; stage 3 versus stage 1, RR, 1.23, $95 \% \mathrm{Cl}$, 1.06-1.42; stage 4 versus stage 1, RR, 1.29, $95 \% \mathrm{Cl}, 1.11-1.51$; stages $2-4$ versus stage 1, RR, 1.24, $95 \% \mathrm{Cl}, 1.10-1.40)$; however, no significantly different risk of EP in women with endometriosis existed between the other stages.
\end{abstract}

Conclusion: The results suggest that it is important to identify whether patients with endometriosis also have EP and then remove any coexisting EP via hysteroscopy, especially for infertile patients. This process will be clinically helpful to treat endometriosis-related infertility in patients with endometriosis, especially for those with endometriosis that is more serious than stage 1 .

Keywords: Endometriosis, Endometrial polyps, Meta-analysis

\section{Background}

Endometriosis is characterized by the presence of endometrial glands and stroma at extrauterine locations and affects approximately $10 \%$ of women of reproductive age, resulting in dysmenorrhea, infertility and decreased quality of life $[1,2]$. Although its exact pathogenesis is unclear, endometriosis is considered to be an estrogendependent disease [3]. The expression patterns of estrogen receptors (ER) and aromatase are both altered in patients

\footnotetext{
*Correspondence: peishuliu@126.com

${ }^{\dagger}$ Equal contributors

'Department of Obstetrics and Gynecology, Qilu Hospital of Shandong University, 107 Wenhua Xi Road, Jinan, Shandong 250012, People's Republic of China

Full list of author information is available at the end of the article
}

with endometriosis [4-6]. Furthermore, estrogen metabolism in the endometrium of patients with endometriosis is quite different from that in normal endometrium [3].

Endometrial polyps (EP), the localized hyperplastic growth of endometrial glands and stroma, can affect up to $25 \%$ of women, especially infertile women [7]. Similar to endometriosis, EP is also believed to be an estrogendependent disease [8]. The concentrations of ER and progesterone receptors (PR) were found to be significantly higher in the endometrium from women with EP than in normal endometrium $[9,10]$. Moreover, the aromatase level was remarkably higher in the endometrium from EP patients than in control endometrium [11]. Recent evidence showed that EP was a potential cause for 
unexplained infertility and that polypectomy significantly increased the pregnancy rate [12].

Because of their common pathogenesis, endometriosis and EP may be associated with each other in some aspects. Emerging evidence suggests a higher frequency of EP in endometriosis patients compared with women without endometriosis [12-15]; however, whether endometriosis patients have a high risk of EP has not been demonstrated. The present article evaluated the association of endometriosis and EP. To investigate whether endometriosis patients have a high risk of EP, we performed a meta-analysis using previously published studies.

\section{Methods}

\section{Search strategy and selection criteria}

For the meta-analysis, we systematically and carefully searched PubMed, Embase, Cochrane Library, as well as Chinese databases, including CNKI (China National Knowledge Infrastructure), VIP (Chinese Scientific Journals Database) and Wanfang for relevant studies available online and published between 1964 and 2014. The search terms "endometriosis and endometrial polyps" or "endometriosis and uterine polyps" or "endometriosis and endometrial neoplasm" were used as key words. The searches were conducted independently by two authors (QM Zheng and YJ Zhao).

The included studies had to meet the following criteria: 1) endometriosis and EP diagnosed by surgery or pathology, 2) clearly described selection of controls, 3) human study, and 4) cohort or case-control study. Articles were excluded if they met the following criteria: 1) case report or review article, 2) animal or cell experiment, or 3) not published in English or Chinese.

\section{Selection of articles and data extraction}

Two authors (QM Zheng and YJ Zhao) independently scanned the titles and abstracts and evaluated the potential eligibility of all of the studies according to the inclusion and exclusion criteria. Any disagreement in the process was resolved by discussion or the third author (J Zhao). The references of the selected articles were also checked for possible studies to include. Data extraction was also performed by the two authors using a standardized datacollection form. The following data were extracted from the eligible studies: the first author, year of publication, study population, study design, numbers of women with and without endometriosis, age, diagnosis of endometriosis and EP, numbers of patients with EP in women with and without endometriosis, numbers of endometriosis patients at r-AFS (revised-American Fertility Society) or AFS (American Fertility Society) stages 1-4, and numbers of women with EP at each stage of endometriosis. For articles lacking the relevant data, an E-mail was sent to the authors to request the information.

\section{Quality assessment}

The quality of each study was independently assessed by the two authors using the Newcastle-Ottawa Scale (NOS), a validated tool for assessing the quality of non-randomized studies in meta-analyses [16]. The NOS uses a star system based on three aspects: selection of the study groups (up to four points), comparability of the groups (up to two points), and exposure or outcome (up to three points) for casecontrol or cohort studies. We included studies with an NOS score $\geq 5$ in the current systematic review and metaanalysis.

\section{Statistical analysis}

We primarily assessed the risk of EP in women with endometriosis compared with those without endometriosis. Further analysis was conducted to evaluate the risk of EP in women with endometriosis according to the stage of endometriosis. The meta-analysis was performed with STATA software (version 12.0 StataCorp, College Station, TX). All of the results for the binary outcomes are shown as the relative risk (RR) with a $95 \%$ confidence interval (CI) in the case-control or cohort studies. The impact of heterogeneity was assessed using Higgins $\mathrm{I}^{2}$ [17]. When $P>0.1$ or $\mathrm{I}^{2} \leq 50 \%$, the fixed effect model using the Mantel-Haensze

1 method was used because it indicated acceptable heterogeneity. Conversely, the random effects model was used when $P<0.1$ or $\mathrm{I}^{2}>50 \%$.

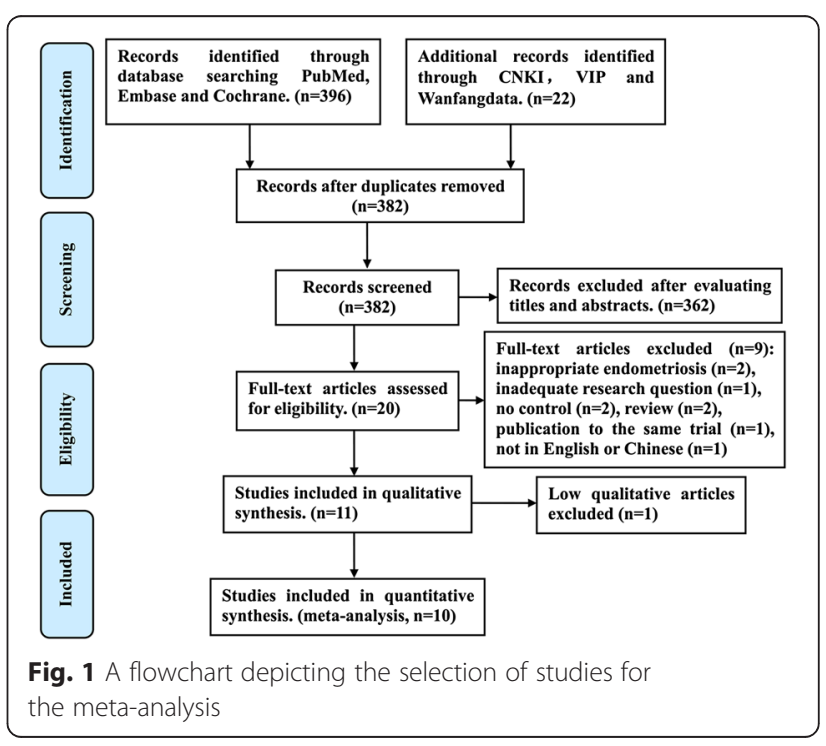


Table 1 Summary of included studies

\begin{tabular}{|c|c|c|c|c|c|c|}
\hline Author, year, place & Study population & Study design & Cases & Controls & Parameter measured & Result \\
\hline McBean, 1996, USA & $\begin{array}{l}\text { Women who had a } \\
\text { HSG, hysteroscopy, } \\
\text { and laparoscopy }\end{array}$ & Case-control & $\begin{array}{l}32 \text { women with } \\
\text { hysterosalpingograms } \\
\text { proved polyps or } \\
\text { polypoid endometrium }\end{array}$ & $\begin{array}{l}88 \text { women with hysterosalpingograms } \\
\text { proved absence of polyps or polypoid } \\
\text { endometrium }\end{array}$ & $\begin{array}{l}\text { Number of patients } \\
\text { with endometriosis }\end{array}$ & Cases: 27; controls: 19 \\
\hline Mi Ran Kim, 2003, Korea & $\begin{array}{l}\text { Infertile women } \\
\text { undergoing } \\
\text { laparoscopy }\end{array}$ & Cohort & $\begin{array}{l}92 \text { (mean age, } \\
30.6 \pm 3.9 \text { years) had } \\
\text { laparoscopy-proved } \\
\text { endometriosis }\end{array}$ & $\begin{array}{l}91 \text { (mean age, } 30.8 \pm 4.6 \text { years) had } \\
\text { laparoscopy-proved absence of } \\
\text { endometriosis }\end{array}$ & $\begin{array}{l}\text { Number (\%) of patients } \\
\text { with endometrial polyps }\end{array}$ & $\begin{array}{l}\text { Cases: } 43 \text { (46.7 \%); } \\
\text { controls: } 15 \text { (16.5 \%) }\end{array}$ \\
\hline Shuyun Zhao, 2006, China & $\begin{array}{l}\text { Infertile women } \\
\text { undergoing } \\
\text { laparoscopy or } \\
\text { laparotomy }\end{array}$ & Cohort & $\begin{array}{l}94 \text { (mean age, } \\
30.6 \pm 4.07 \text { years) } \\
\text { had laparoscopy-proved } \\
\text { endometriosis }\end{array}$ & $\begin{array}{l}98 \text { (mean age, } 30.8 \pm 3.4 \text { years) had } \\
\text { laparoscopy-proved chronic pelvic } \\
\text { inflammation; } 116 \text { (mean age, } \\
30.7 \pm 2.61 \text { years) had laparoscopy-proved } \\
\text { normal pelvic }\end{array}$ & $\begin{array}{l}\text { Number (\%) of patients } \\
\text { with endometrial polyps }\end{array}$ & $\begin{array}{l}\text { Cases: } 20(21.3 \%) \text {; chronic } \\
\text { pelvic inflammation: } 4 \\
\text { ( } 4.1 \%) \text {; normal pelvic: } \\
4(3.4 \%)\end{array}$ \\
\hline Jae Sun Park, 2009, Korea & $\begin{array}{l}\text { Infertile women } \\
\text { undergoing } \\
\text { laparoscopy }\end{array}$ & Cohort & $\begin{array}{l}434 \text { (mean age, } \\
31.38 \pm 4.37 \text { years) } \\
\text { had laparoscopy-proved } \\
\text { endometriosis }\end{array}$ & $\begin{array}{l}197 \text { (mean age, } 31.05 \pm 5.48 \text { years) } \\
\text { had laparoscopy-proved the absence } \\
\text { of endometriosis }\end{array}$ & $\begin{array}{l}\text { Number (\%) of patients } \\
\text { with endometrial polyps }\end{array}$ & $\begin{array}{l}\text { Cases: } 274 \text { (63.0 \%); } \\
\text { controls: } 58 \text { (29.8\%) }\end{array}$ \\
\hline Licong Shen, 2011, China & $\begin{array}{l}\text { Infertile women } \\
\text { undergoing } \\
\text { simultaneous } \\
\text { laparoscopy and } \\
\text { hysteroscopy }\end{array}$ & Cohort & $\begin{array}{l}158 \text { (mean age, } \\
31.0 \pm 4.2 \text { years) had } \\
\text { laparoscopy-proved } \\
\text { endometriosis }\end{array}$ & $\begin{array}{l}273 \text { (mean age, } 30.7 \pm 5.3 \text { years) } \\
\text { had no endometriotic foci found } \\
\text { during laparoscopy }\end{array}$ & $\begin{array}{l}\text { Number (\%) of patients } \\
\text { with endometrial polyps }\end{array}$ & $\begin{array}{l}\text { Cases: } 108 \text { (68.35 \%); } \\
\text { controls: } 56 \text { (20.51\%) }\end{array}$ \\
\hline Yubin Li, 2011, China & $\begin{array}{l}\text { Infertile women } \\
\text { aged } 21-42 \text { years } \\
\text { undergoing laparoscopy } \\
\text { and hysteroscopy }\end{array}$ & Cohort & $\begin{array}{l}84 \text { (mean age, } \\
30.87 \pm 4.5 \text { years) had } \\
\text { laparoscopy-proved } \\
\text { endometriosis }\end{array}$ & $\begin{array}{l}160 \text { (mean age, } 30.87 \pm 4.5 \text { years) } \\
\text { had laparoscopy-proved the absence } \\
\text { of endometriosis }\end{array}$ & $\begin{array}{l}\text { Number (\%) of patients } \\
\text { with endometrial polyps }\end{array}$ & $\begin{array}{l}\text { Cases: } 16 \text { (19.0 \%); } \\
\text { controls: } 12 \text { (7.5\%) }\end{array}$ \\
\hline Hong Jin, 2013, China & $\begin{array}{l}\text { Women undergoing } \\
\text { surgery or physical } \\
\text { examination }\end{array}$ & Cohort & $\begin{array}{l}150 \text { aged } 23-53 \text { (mean } \\
\text { age, } 41.8 \text { years) had } \\
\text { surgery and pathology } \\
\text { proved endometriosis }\end{array}$ & $\begin{array}{l}158 \text { aged } 23-53 \text { (mean age, } \\
39.11 \text { years) had ultrasound proved } \\
\text { the absence of endometriosis }\end{array}$ & $\begin{array}{l}\text { Number (\%) of patients } \\
\text { with endometrial polyps }\end{array}$ & $\begin{array}{l}\text { Cases: } 23 \text { (15.33 \%); } \\
\text { controls: } 10 \text { (6.33 \%) }\end{array}$ \\
\hline Fuqin Li, 2013, China & $\begin{array}{l}\text { Infertile women aged } \\
20-42 \text { years undergoing } \\
\text { laparoscopy and } \\
\text { hysteroscopy }\end{array}$ & Cohort & $\begin{array}{l}42 \text { (mean age, } \\
28.5 \pm 2.5 \text { years) had } \\
\text { laparoscopy-proved } \\
\text { endometriosis }\end{array}$ & $\begin{array}{l}78 \text { (mean age, } 28.5 \pm 2.5 \text { years) } \\
\text { had laparoscopy-proved the absence } \\
\text { of endometriosis }\end{array}$ & $\begin{array}{l}\text { Number (\%) of patients } \\
\text { with endometrial polyps }\end{array}$ & $\begin{array}{l}\text { Cases: } 8 \text { (19.0 \%); } \\
\text { controls: } 4 \text { (5.1 \%) }\end{array}$ \\
\hline Yanru Li, 2013, China & $\begin{array}{l}\text { Infertile women, aged } \\
20-42 \text { years undergoing } \\
\text { laparoscopy and } \\
\text { hysteroscopy }\end{array}$ & Cohort & $\begin{array}{l}81 \text { (mean age, } \\
29.5 \pm 4.71 \text { years) had } \\
\text { laparoscopy-proved } \\
\text { endometriosis }\end{array}$ & $\begin{array}{l}110 \text { (mean age, } 29.5 \pm 4.71 \text { years) } \\
\text { had laparoscopy-proved the absence } \\
\text { of endometriosis }\end{array}$ & $\begin{array}{l}\text { Number (\%) of patients } \\
\text { with endometrial polyps }\end{array}$ & $\begin{array}{l}\text { Cases: } 17(21 \%) ; \\
\text { controls: } 8 \\
(7.3 \%)\end{array}$ \\
\hline Gaixiang Xu, 2014, China & $\begin{array}{l}\text { Infertile women } \\
\text { undergoing simultaneous } \\
\text { laparoscopy and } \\
\text { hysteroscopy }\end{array}$ & Cohort & $\begin{array}{l}119 \text { (mean age, } 31.1 \pm 3.0 \\
\text { years) had laparoscopy-proved } \\
\text { endometriosis }\end{array}$ & $\begin{array}{l}241 \text { (mean age, } 30.7 \pm 4.1 \text { years) } \\
\text { had laparoscopy-proved the absence } \\
\text { of endometriosis }\end{array}$ & $\begin{array}{l}\text { Number (\%) of patients } \\
\text { with endometrial polyps }\end{array}$ & $\begin{array}{l}\text { Cases: } 77 \text { (64.7 \%); } \\
\text { controls: } 51 \text { (21.16\%) }\end{array}$ \\
\hline
\end{tabular}


To establish the robustness of our results, a sensitivity analysis was performed by recalculating the pooled RR after deleting the studies one at a time. To identify the presence of publication bias, a funnel plot was produced using the $\log R \mathrm{R}$ of each study on the $\mathrm{X}$-axis and the standard error of the logRR of each study on the Y-axis. Furthermore, the Harbord test was used to test the symmetry of the funnel plot. $P>0.5$ suggested that the funnel plot was symmetric and that no significant publication bias existed.

\section{Results}

\section{Included studies and quality assessment}

As shown in Fig. 1, we collected 418 articles from the databases. After deleting the duplicates and screening titles and abstracts, 20 articles remained for eligibility assessment. Of the 20 studies selected after searching the database, only 11 studies were found to meet the inclusion criteria. The 11 studies, including 10 cohort studies and 1 case-control study, were published between 1996 and 2014. Of the 11 studies, one was excluded for its NOS score $<5$. Therefore, 9 cohort studies [12, 13, 15, 18-23] and 1 case-control study [24] including 1286 women with endometriosis and 1610 women without endometriosis were included in the meta-analysis (Table 1 ). The studies were conducted in the United States $(n=1)$, Korea $(n=2)$, and China $(n=7)$. The NOS scores of the 10 included studies ranged from 5 to 7 (Additional file 1: Table S1), and the mean score was $6.1( \pm$ SEM 0.2769). Of the 10 studies, only 5 studies analyzed the association of EP in women with endometriosis according to AFS or r-AFS stages. The NOS scores of the 5 studies ranged from 6 to 7 (Additional file 2: Table S2), and the mean score was 6.8 ( \pm SEM 0.20).

\section{Outcomes}

The fixed effect model with the Mantel-Haenszel method was used because no obvious heterogeneity was found $\left(P=0.146, \mathrm{I}^{2}=32.8 \%\right.$, Fig. 2). As depicted in Fig. 2, the pooled RR of 2.81 (95\% CI, 2.48-3.18) revealed that the risk of EP increased in women with endometriosis $(47.67 \%)$ compared with those without endometriosis $(14.97 \%)$. Then, we analyzed the risk of $\mathrm{EP}$ in women with different stages of endometriosis. For the articles reporting the association of EP in women with endometriosis according to AFS or r-AFS stages, the results of the heterogeneity tests were $P>0.1, \mathrm{I}^{2}=0 \%$ (Figs. 3 and 4, Additional file 3: Figure S1 and Additional file 4: Figure S2). Therefore, the fixed effect model with the Mantel-Haenszel method was used to calculate the pooled RR. As shown in Figs. 3 and 4, the risk of EP slightly increased in women with endometriosis at stages 2-4 (61.46, 61.64 and $64.20 \%)$ when compared with those at stage 1 (51.38 \%. Pooled effect size: stage 2 versus stage 1, RR, 1.22, $95 \%$ CI, 1.04-1.42; stage 3 versus stage 1, RR, 1.23, 95 \% CI, 1.06-1.42; stage 4 versus stage 1 , RR, 1.29,

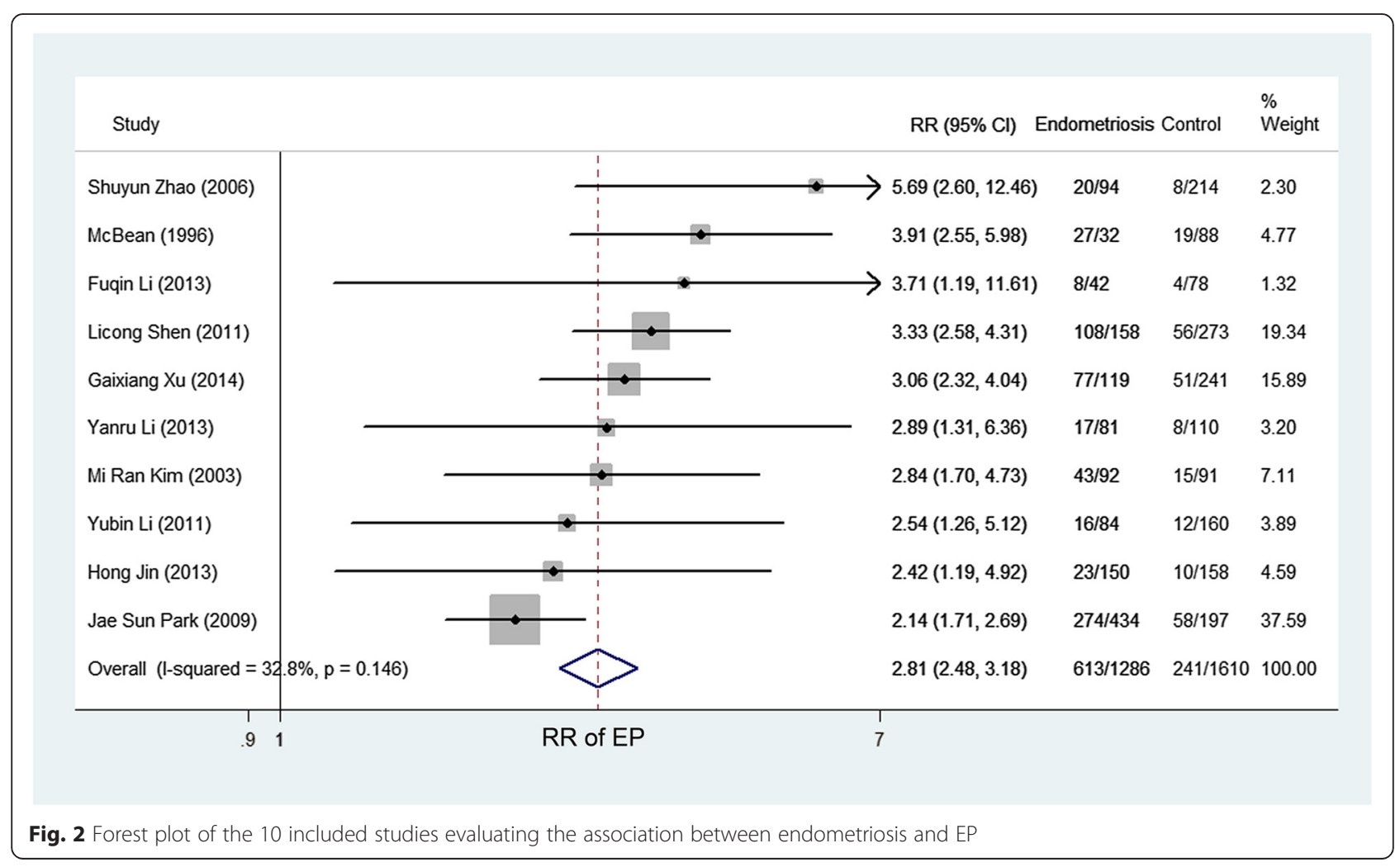




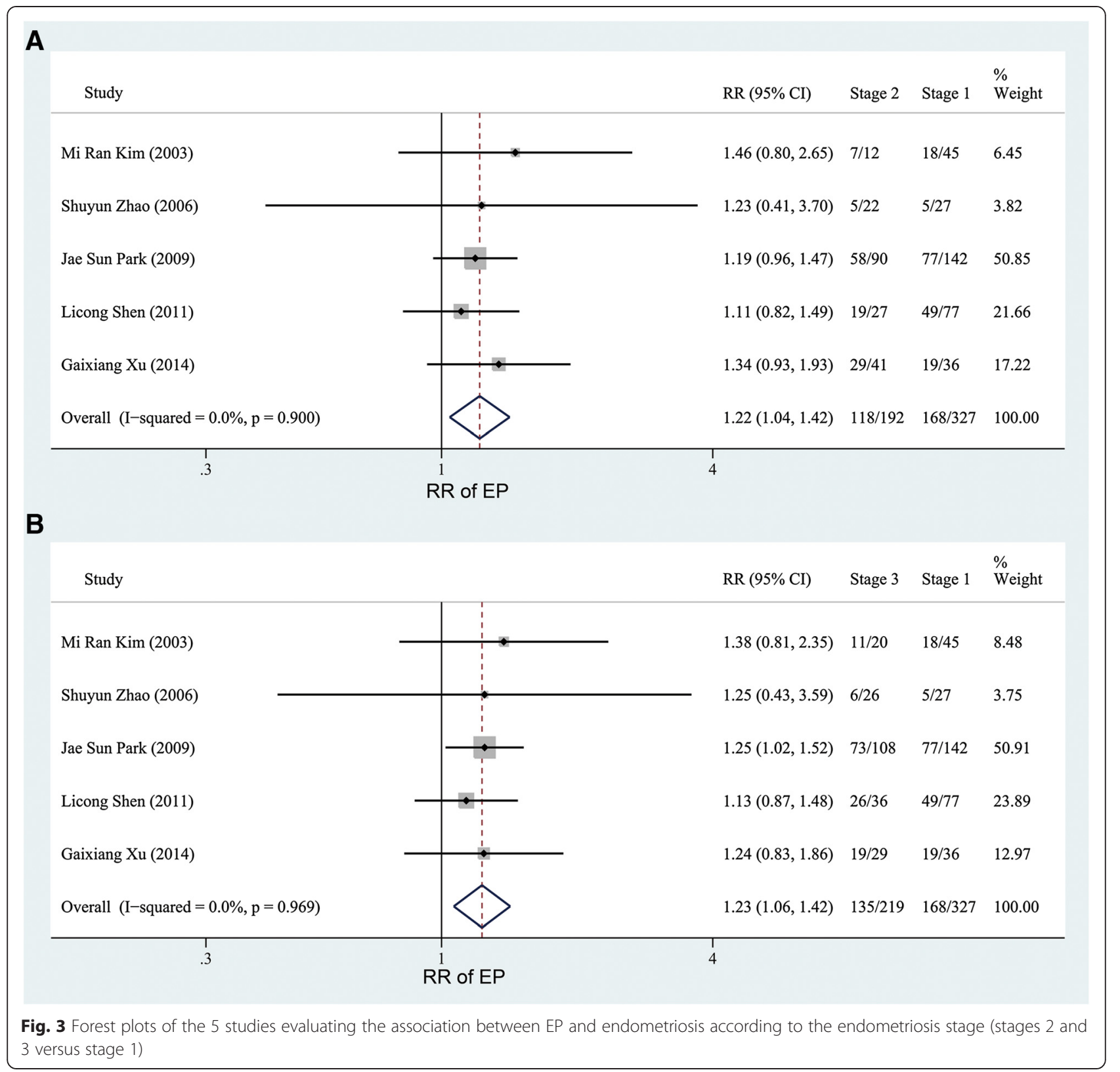

$95 \% \mathrm{CI}, 1.11-1.51$; stages $2-4$ versus stage $1, \mathrm{RR}, 1.24$, $95 \%$ CI, 1.10-1.40). However, no significantly different risk of EP in women with endometriosis existed between the other stages (Additional file 3: Figure S1 and Additional file 4: Figure S2).

\section{Publication bias and sensitivity analysis}

As indicated in Fig. 5, the funnel plot was visually symmetric. Then, the Harbord plot was used to test the symmetry of the funnel plot. The funnel plot was considered symmetric because the regression line had a positive slope through the origin of the coordinates $(P=0.973)$. Therefore, no obvious publication bias existed in the current meta-analysis. A sensitivity analysis was performed to evaluate whether any small study effect influenced the pooled effect size. No significant changes were observed in the leave-one-out sensitivity analysis (Fig. 6). Thus, the outcome of the current meta-analysis can be considered to be stable.

\section{Discussion}

In this meta-analysis of cohort and case-control studies evaluating the association between EP and endometriosis, we found a significantly increased risk of EP in women with endometriosis compared with those without endometriosis. Moreover, the risk of EP in women 


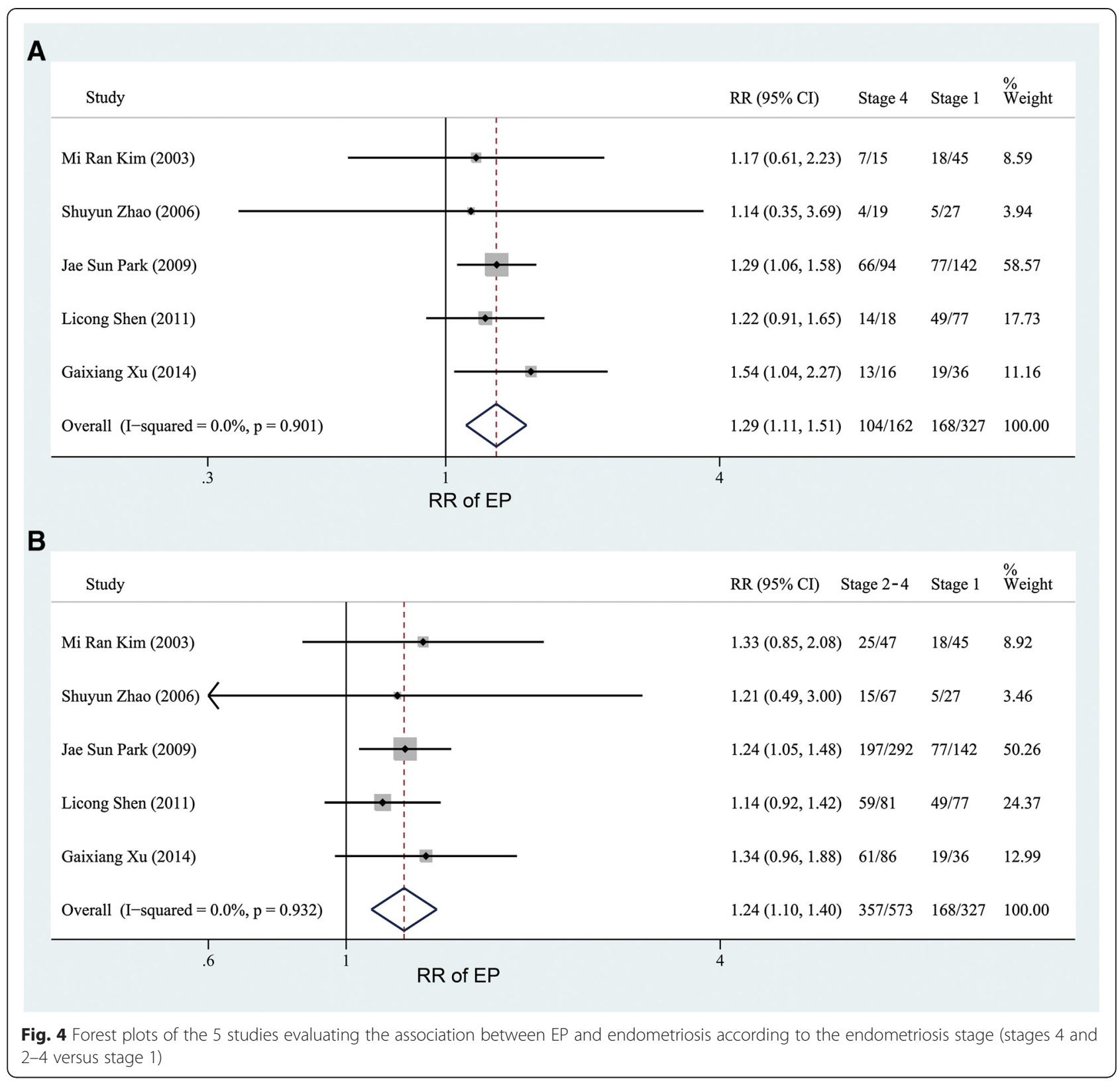

with endometriosis slightly increased at stages 2-4 compared with those at stage 1; however, no significant difference was found for the risk of EP in women with endometriosis at stage 2 , stage 3 or stage 4 . Therefore, endometriosis patients have a significantly high risk of $E P$, especially for endometriosis that is more serious than stage 1.

The precise pathogenesis of endometriosis or EP is not clear. The most widely accepted theory is that the two diseases are both estrogen dependent $[3,8]$. EP is the localized hyperplastic growth of endometrial glands and stroma, while endometriosis is the ectopic growth of endometrial glands and stroma. Both diseases include the overgrowth of the endometrium, a process that requires the support of estrogen. The expression patterns of ER and aromatase are both altered in endometriosis and EP patients $[4,6,9,11]$. As an enzyme, aromatase can catalyze the conversion of androgen to estrogen, increasing the local concentration of estrogen. Estrogen metabolism, including aromatase and $17 \beta$-hydroxysteroid dehydrogenase type 2 (17ßHSD2, an enzyme that inactivates estradiol to estrone), is altered in the eutopic endometrium of women with endometriosis compared with the eutopic endometrium of women without endometriosis [3]. Additionally, increased proliferation and decreased apoptosis have been observed in the eutopic endometrium of women with endometriosis compared with 

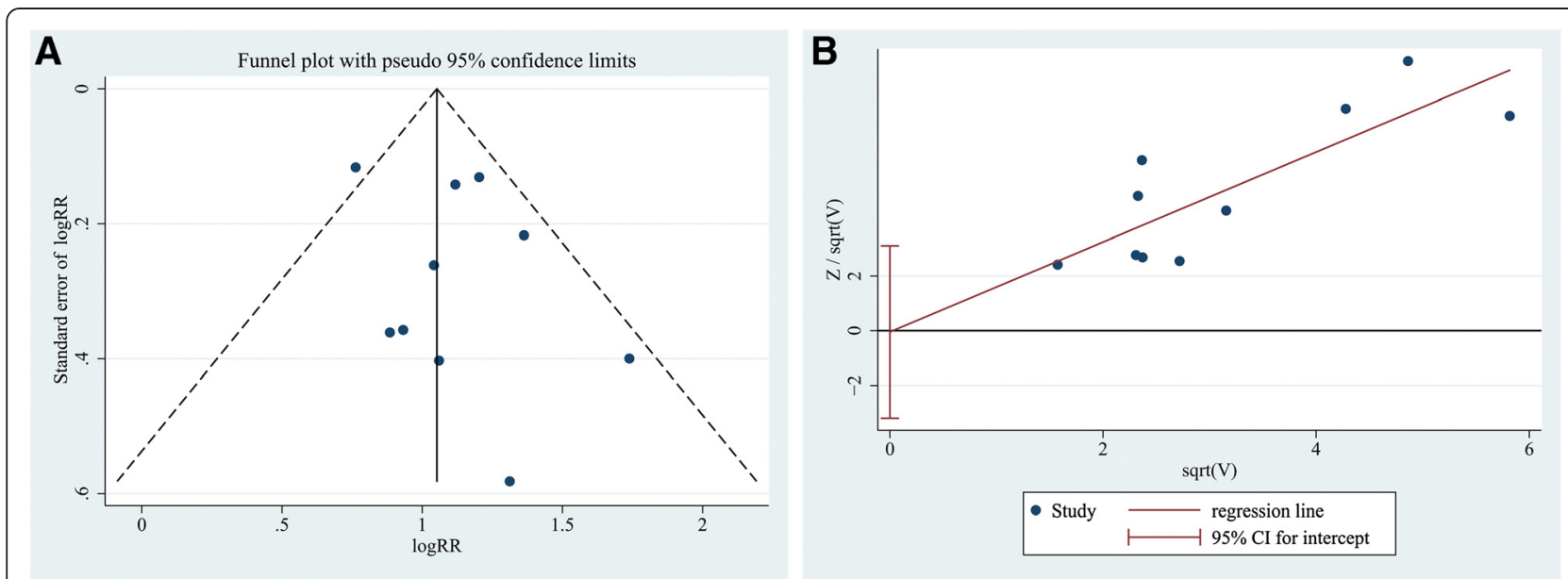

Fig. 5 a Funnel plot, using data from the 10 studies evaluating the association between endometriosis and EP, with the logRR of each study on the $\mathrm{X}$-axis and the standard error of the logRR on the $\mathrm{Y}$-axis. $\mathbf{b}$ Harbord plot testing the symmetry of the funnel plot

women without endometriosis [15, 25]. As a regulator of apoptosis, Bcl-2 was shown to be significantly increased in the eutopic endometrium of women with endometriosis, leading to the inhibition of apoptosis in the endometrium [26]. Herein, the eutopic endometrium in women with endometriosis was found to be different from that of women without endometriosis. Increased proliferation, decreased apoptosis and altered estrogen metabolism in the endometrium of women with endometriosis facilitated the presence of EP.

McBean first reported the association of endometriosis and EP in 1996 [24]. Since then, several studies have shown a higher frequency of EP in endometriosis patients than in women without endometriosis [12-15]. In accordance with previous studies, the present meta-analysis confirmed a significantly high risk of EP in women with endometriosis. Furthermore, the risk of EP was increased in endometriosis patients at stages 2-4 when compared with those at stage 1 . No significant heterogeneity, small study effect or publication bias was found in the metaanalysis.

Although endometriosis patients were statistically shown to have a high risk of EP, this result should be carefully comprehended for the following reasons. First, only studies published in English and Chinese were included in this meta-analysis, and thus, studies published in other languages were omitted. Second, the pooled RR of the current meta-analysis may not be accurate because only a small number of studies were included. Third, the risk of EP in the endometriosis patients

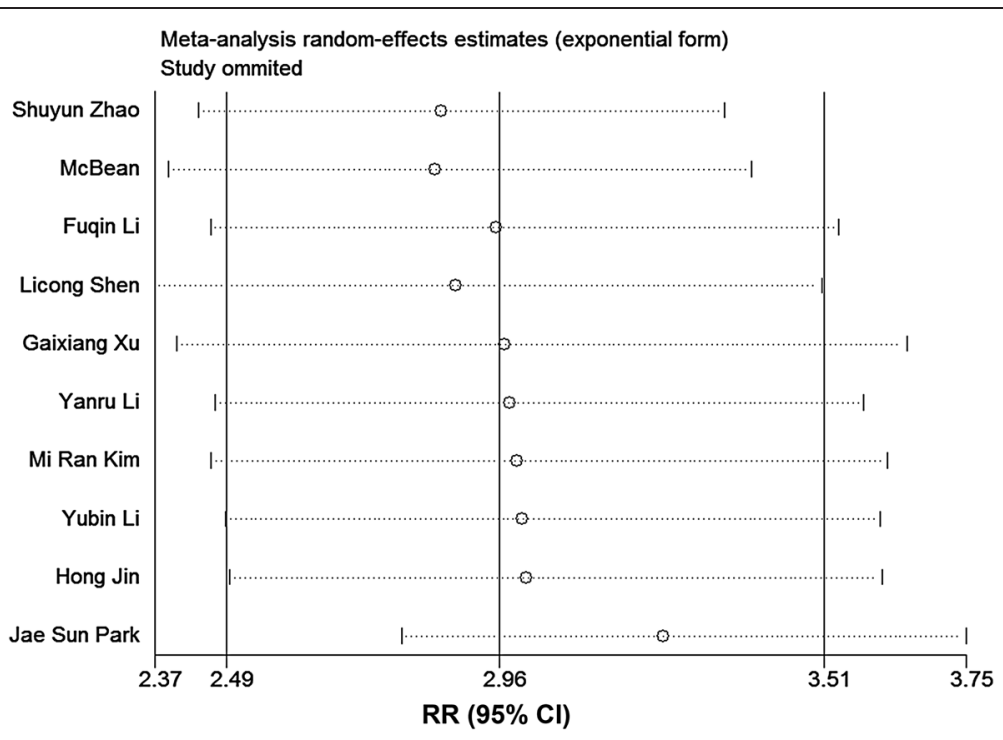

Fig. 6 Sensitivity analysis of the meta-analysis 
according to the endometriosis stage needs to be further ascertained because the included studies did not use consistent staging criteria for endometriosis. Consequently, this meta-analysis should be updated if studies addressing the association of endometriosis and EP are published in the future.

\section{Conclusion}

The results suggest that it is important to determine whether patients with endometriosis also have EP and then remove any coexisting EP via hysteroscopy, especially for infertile patients. This procedure will be clinically helpful to treat endometriosis-related infertility in patients with endometriosis, especially for those with endometriosis that is more serious than stage 1 .

\section{Additional files}

Additional file 1: Table S1. Quality of included studies using Newcastle-Ottawa scale. (DOC 38 kb)

Additional file 2: Table S2. Quality of studies analyzed the association of EP and endomeriosis stages using Newcastle-Ottawa scale. (DOC $30 \mathrm{~kb}$ )

Additional file 3: Figure S1. Forest plots of the 5 studies evaluating the association between EP and endometriosis according to the endometriosis stage (stages 3 and 4 versus stage 2). (TIFF 2120 kb)

Additional file 4: Figure S2. Forest plots of the 5 studies evaluating the association between EP and endometriosis according to the endometriosis stage (stage 4 versus stage 1 , and stages $3-4$ versus stages 1-2). (TIFF $2134 \mathrm{~kb}$ )

\section{Abbreviations}

EP: Endometrial polyps; ER: Estrogen receptors; PR: Progesterone receptors; CNKI: China National Knowledge Infrastructure; VIP: Chinese Scientific Journals Database; r-AFS: Revised-American Fertility Society; AFS: American Fertility Society; NOS: The Newcastle-Ottawa Scale; RR: Relative risk; $\mathrm{Cl}$ : Confidence interval; SEM: Standard error of the mean; 17ßHSD2: 17及hydroxysteroid dehydrogenase type 2 .

\section{Competing interests}

The authors declare that they have no competing interests.

\section{Author's contribution}

Q-MZ conducted article selection, data extraction, and article quality assessment and wrote the manuscript. H-LM conducted article revision. $\mathrm{Y}$-JZ conducted selection of articles, data extraction and quality assessment of articles. JZ provided helpful discussion and critical analysis of data. XW provided critical analysis of data. P-SL supervised the overall project and edited the manuscript.

\section{Acknowledgments}

This study was supported by grants from the National Natural Science Foundation of China (No. 81370696 and 81101984) and the Science and Technology Development Planning of Shandong (2013GGE27031).

\section{Author details}

${ }^{1}$ Department of Obstetrics and Gynecology, Qilu Hospital of Shandong University, 107 Wenhua Xi Road, Jinan, Shandong 250012, People's Republic of China. 'Department of Surgery, 92403 Military Hospital, 38 Luoxing Xi Road, Fuzhou, Fujian 350015, People's Republic of China.
Received: 4 June 2015 Accepted: 6 August 2015

Published online: 17 September 2015

\section{References}

1. Culley L, Law C, Hudson N, Denny E, Mitchell H, Baumgarten M, et al. The social and psychological impact of endometriosis on women's lives: a critical narrative review. Hum Reprod Update. 2013;19:625-39.

2. Viganò P, Parazzini F, Somigliana E, Vercellini P. Endometriosis: epidemiology and aetiological factors. Best Pract Res Clin Obstet Gynaecol. 2004;18:177-200.

3. Kitawaki J, Kado N, Ishihara H, Koshiba H, Kitaoka Y, Honjo H. Endometriosis: the pathophysiology as an estrogen-dependent disease. J Steroid Biochem Mol Biol. 2002:83:149-55.

4. Jones RK, Bulmer JN, Searle RF. Immunohistochemical characterization of proliferation, oestrogen receptor and progesterone receptor expression in endometriosis: comparison of eutopic and ectopic endometrium with normal cycling endometrium. Hum Reprod. 1995;10:3272-9.

5. Pellegrini C, Gori l, Achtari C, Hornung D, Chardonnens E, Wunder D, et al. The expression of estrogen receptors as well as GREB1, c-MYC, and cyclin D1, estrogen-regulated genes implicated in proliferation, is increased in peritoneal endometriosis. Fertil Steril. 2012;98:1200-8.

6. Noble LS, Simpson ER, Johns A, Bulun SE. Aromatase expression in endometriosis. J Clin Endocrinol Metab. 1996;81:174-9.

7. de Sa Rosa e de Silva AC, Rosa e Silva JC, Reis FJ C d, Nogueira AA, Ferrian RA. Routine office hysteroscopy in the investigation of infertile couples before assisted reproduction. J Reprod Med. 2005;50:501-6.

8. Indraccolo U, Di lorio R, Matteo M, Corona G, Greco P, Indraccolo SR. The pathogenesis of endometrial polyps: a systematic semi-quantitative review. Eur J Gynaecol Oncol. 2013;34:5-22.

9. Lopes RG, Baracat EC, de Albuquerque Neto LC, Ramos JF, Yatabe S, Depesr $D B$, et al. Analysis of estrogen- and progesterone-receptor expression in endometrial polyps. J Minim Invasive Gynecol. 2007;14:300-3.

10. Sant'Ana de Almeida EC, Nogueira AA, Candido dos Reis FJ, Zambelli Ramalho LN, Zucoloto S. Immunohistochemical expression of estrogen and progesterone receptors in endometrial polyps and adjacent endometrium in postmenopausal women. Maturitas. 2004;49:229-33.

11. Maia Jr H, Pimentel K, Silva TM, Freitas LA, Zausner B, Athayde C, et al. Aromatase and cyclooxygenase-2 expression in endometrial polyps during the menstrual cycle. Gynecol Endocrinol. 2006;22:219-24.

12. Shen L, Wang Q, Huang W, Yuan Q, Huang Y, Lei H. High prevalence of endometrial polyps in endometriosis-associated infertility. Fertil Steril. 2011;95:2722-4. e2721.

13. Kim MR, Kim YA, Jo MY, Hwang KJ, Ryu HS. High frequency of endometrial polyps in endometriosis. J Am Assoc Gynecol Laparosc. 2003;10:46-8.

14. Kontoravdis A, Augoulea A, Lambrinoudaki I, Christodoulakos G, Tzortziotis D, Grammatikakis I, et al. Ovarian endometriosis associated with ovarian cancer and endometrial-endocervical polyps. J Obstet Gynaecol Res. 2007;33:294-8.

15. Park JS, Lee JH, Kim M, Chang HJ, Hwang KJ, Chang KH. Endometrium from women with endometriosis shows increased proliferation activity. Fertil Steril. 2009:92:1246-9.

16. Wells GA, Shea B, O'Connell D, Peterson J, Welch V, Losos M, et al. The Newcastle-Ottawa Scale (NOS) for assessing the quality of nonrandomised studies in meta-analyses. Canada: Department of Epidemiology and Community Medicine, University of Ottawa; 2012.

17. Higgins JP, Thompson SG, Deeks JJ, Altman DG. Measuring inconsistency in meta-analyses. BMJ. 2003;327:557-60.

18. Yanru L, Dehong Y. Study of the association of endmetrial polyps and endometriosis. World Health Digest Medical Periodieal. 2013;10:161-2.

19. Shuyun Z, Yusheng L, Luo L, Hongbing L, Jingjuan J. Comparison of incidence of endometrial polyps in three types infertile women. Maternal and Child Health Care of China. 2006;21:1120-1.

20. Xu G, Wang B, Shen A, Shunhong Z. Correlation between endometriosis-associated infertility and endometrial polyps. Journal of Chinese Practical Diagnosis and Therapy. 2014;28:355-7.

21. Hong J. The research of the endometrial polyps in commen gynecological disease. [D]. Xinjiang: Xinjiang Medical University, 2013:1-27.

22. Fuqin L. Relevance analysis between endometrial polyps and infertility. Chinese Journal of Practical Medicine. 2013;40:60-1.

23. Li Yubin O, Jianping MQ, Canquan Z. The relevance analysis between infertility and endometrial polyps. J Practic Obstet Gynaecol. 2011;27:852-5. 
24. McBean JH, Gibson M, Brumsted JR. The association of intrauterine filling defects on hysterosalpingogram with endometriosis. Fertil Steril. 1996;66:522-6.

25. Dmowski WP, Ding J, Shen J, Rana N, Fernandez BB, Braun DP. Apoptosis in endometrial glandular and stromal cells in women with and without endometriosis. Hum Reprod. 2001;16:1802-8.

26. Harada T, Taniguchi F, Izawa M, Ohama Y, Takenaka Y, Tagashira Y, et al. Apoptosis and endometriosis. Front Biosci. 2007;12:3140-51.

Submit your next manuscript to BioMed Central and take full advantage of:

- Convenient online submission

- Thorough peer review

- No space constraints or color figure charges

- Immediate publication on acceptance

- Inclusion in PubMed, CAS, Scopus and Google Scholar

- Research which is freely available for redistribution 